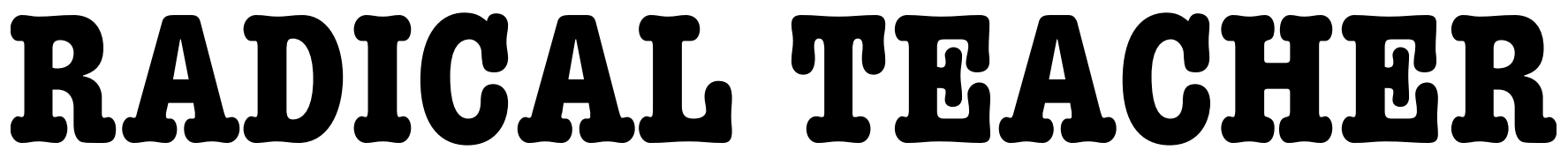

A SOCIALIST, FEMINIST, AND ANTI-RACIST JOURNAL ON THE THEORY AND PRACTICE OF TEACHING

\title{
The Decline of the Professions: Introduction
}

\author{
By Richard Ohmann and Ellen Schrecker
}

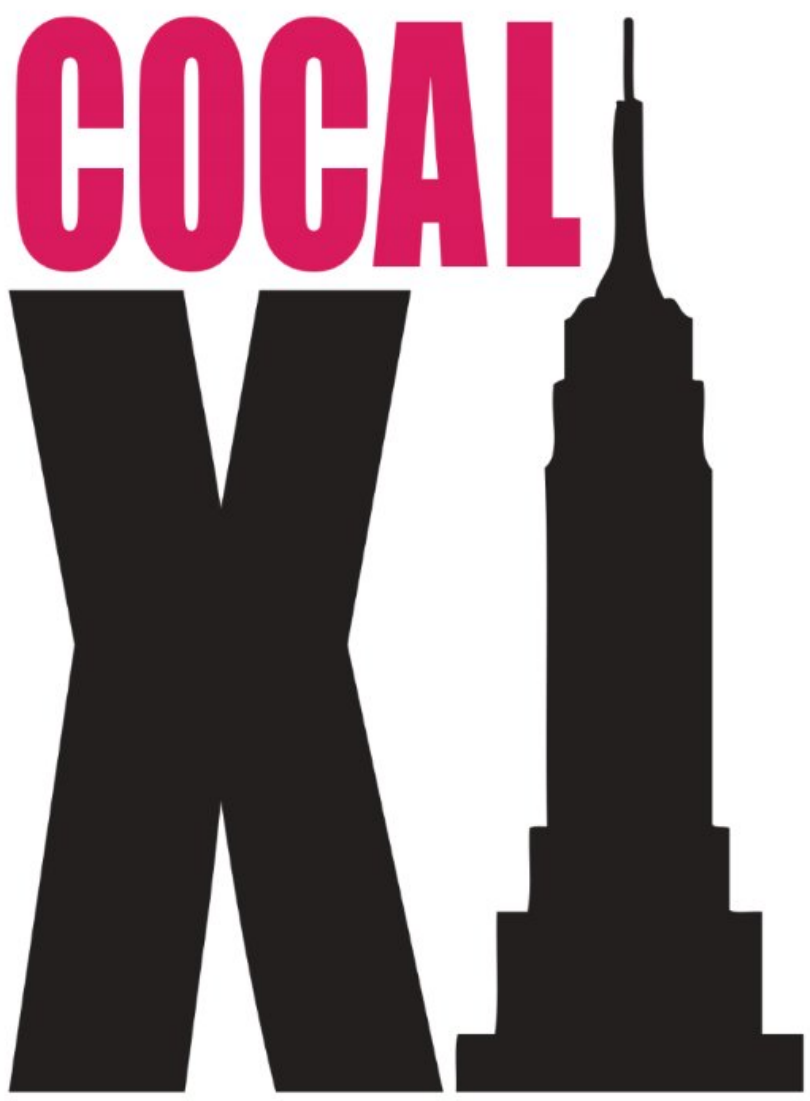

COURTESY OF JOE BERRY, AN ORGANIZER WITH THE COALITION OF CONTINGENT ACADEMIC LABOR (COCAL), A GRASSROOTS COALITION OF ACTIVISTS IN NORTH AMERICA WORKING FOR CONTIGENT FACULTY: ADJUNCT, PART-TIME, NON-TENURED, AND GRADUATE TEACHING FACULTY. LOOK AT THE NEWS FOR EDUCATIONAL WORKERS COLUMN IN THIS ISSUE FOR AN ANNOUNCEMENT OF COCAL'S $11^{\text {TH }}$ ANNUAL CONVENTON IN NEW YORK CITY. 
"A Lawyer and Partner and Also Bankrupt" is the headline of a story in the New York Times, as we begin this introduction. When the firm in which the 55-year-old man had been a partner collapsed, he joined another prominent firm, but took a backward career step, from full, equity partner to "service" partner. Service partners "do not share the risks and rewards of the firm's practice," have no clients of their own, have no job security. These "partners" are, well, employees. There are more and more of them: $84 \%$ of the largest firms have service partners now, up $20 \%$ since 2000. Law firms are consolidating, cost-cutting. There has been a decades-long drop in the percentage of lawyers who make partner. Now the number of associates is declining, too (Stewart). These are all people with law degrees; no wonder law school enrollment drops, as the traditional career becomes a rarity, and ever more highly trained labor becomes contingent. That is without mentioning the army of paralegals and others with lesser credentials, or the commodifying of legal documents and do-it-yourself services on line. One of us asked his country lawyer about these changes. The attorney said, in effect: by the time I retire, law practices like mine will be defunct.

Those of you teaching in the arts and sciences will note similarities. The paradigm of an academic careerdoctoral study, then a well charted ascent through the ranks, culminating in 25 or 30 or so years as a full professor, and tapering off with many years on an ample pension-was never guaranteed or anything like universal, but was a reasonable aspiration for a college graduate who loved physics or sociology or art history. Now, getting the Ph.D. guarantees roughly nothing, except a load of debt. In history and literary studies, $3 / 4$ or 4/5 of entering Ph.D. students want to be teachers and scholars on the tenure track at colleges and universities. Roughly half of those who complete their degrees in a given year will move directly into such jobs. Some of the others will eventually make the tenure track, after adjuncting for a while. Some will be contingent faculty members forever. And some will find other lines of work. Starting over in a different profession might look good. Law school might look good, even as news about the marketability of its "product" grows dire and as stories of bankrupt senior not-quitepartners make the New York Times.

Consider the same picture now as a snapshot of an occupational labor force. Of those teaching in colleges and universities, around $75 \%$ are contingent workers: short contracts, no assurance of renewal, low pay, maybe health insurance but probably not, no pension fund, little if any say in faculty governance or in the making of curriculum, maybe no office and no phone, maybe several other jobs off the tenure track. Many adjuncts have Ph.D.s; many have M.A.s; and many, like real estate agents, computer programmers, or dietitians who moonlight at community colleges or for-profit universities, have no degree that traditionally qualified people for college teaching. It is a lot like the legal work force. In both professions, the old, secure and privileged core has been shrinking for decades, and the periphery of part-timers, adjuncts, contingent workers, service partners, and so on (the names proliferate) has grown. Some of the peripherals have core degrees, many (e.g., paralegals) do not. A larger and larger part of the profession's work is done on line. By whom, one might ask? By poorly paid pieceworkers; by the student or client herself. And cui bono? The for-profit employer of piece workers, or the administration at Defunded State U., or . . . . More about that, soon.

This issue of Radical Teacher puts on display more examples of professional decline. The ones just mentioned have to do with weakening the semi-monopolies that strong professions maintained in specific areas of work: the adjudication of disputes (law), and instruction in colleges and universities. Articles in this issue add examples from other fields. Even medicine, long at the pinnacle of the professional universe, now keeps doctors focused on their computer screens by the electronic record keeping systems that (as Matt Anderson shows) deflect them from paying attention to their patients. And not only do medical practices contain ever more numerous helpers and specialized practitioners with less training and lower pay than physicians, but Walmart and other marketers are now turning the work of healing into a retail business.

\section{The paradigm of an academic career-doctoral study, then a well charted ascent through the ranks, culminating in $\mathbf{2 5}$ or $\mathbf{3 0}$ or so years as a full professor, and tapering off with many years on an ample pension-was never guaranteed or anything like universal, but was a reasonable aspiration for a college graduate who loved physics or sociology or art history. Now, getting the Ph.D. guarantees roughly nothing, except a load of debt.}

Weaker professions have lost ground, too. As readers of this journal know well, $\mathrm{K}-12$ teachers have less and less control over what and how they teach. Lightly trained Teach for America recruits and many others without the old, state-mandated credentials, are taking classroom jobs from $\mathrm{K}-12$ teachers and saving money for school districts. These short-term teachers are especially common in the charter schools that are now most of what survives in public school systems like Philadelphia's and New Orleans' (see Magali Sarfatti Larson's article in this issue). In Canada, as Tami Oliphant and Michael B. McNally note, librarians no longer catalogue books, so much as input squibs sent by publishers, while research with documents that was previously done by librarians and archivists is outsourced to for-profit genealogical companies. In journalism, always one of the less organized professions, bloggers paid little or nothing now do a vast portion of online journalism, while newspaper and television jobs vanish (see C. W. Anderson, below).

Similar reassignments of professional labor in other fields come readily to mind. Work is outsourced to 
engineers and radiologists in India who are paid one-fifth as much as their displaced counterparts in the United States. Tax-preparation chains like H.\&R. Block take over the tasks of professional accountants, if they are not already being replaced by do-it-yourself taxpayers themselves, using software from the Internet. Not to mention more complex or chaotic, unplanned shifts such as the closing of public mental hospitals with a consequent flow of the emotionally ill onto the streets and often, then, into prisons--some run for profit.

We have focused on the loss of professional jobs. That loss, along with the failure of many professional school graduates to find the careers they expected, challenges the credibility of professional education generally. The articles in this issue by Michael Olivas and Paul Campos provide differing analyses of this "crisis" in legal education. Chris Anderson writes about the ever slimmer chance that going to journalism school will open the door to a career in the print or broadcast media. Other symptoms of decline: Bosses increasingly manage the work of professionals (over half of doctors and lawyers now work for salaries). Professions like these two become increasingly stratified; some with the right credentials get rich while others who are equally qualified get crumbs. For-profit companies take over the work of traditional professionals. And, in the world of $\mathrm{K}-12$ education, federal regulations and planning move into areas such as curriculum formerly under the control of teachers' groups and local school boards- c.f. No Child Left Behind.

By contrast, ever since the professions more or less formally organized themselves at the end of the $19^{\text {th }}$ and beginning of the $20^{\text {th }}$ centuries, practitioners enjoyed a prestigious and economically secure work life. They achieved it by asserting and defending a monopoly over a particular occupation. In so doing, they managed, as Magali Sarfatti Larson noted in her path-breaking 1977 study, "to translate one order of scarce resources - special knowledge and skills - into another - social and economic rewards" (Larson, xvii. We are pleased to publish her retrospective on and updating of her 1977 analysis in this issue of Radical Teacher). The process of obtaining what sociologist Andrew Abbott calls their "jurisdictions" or their ability to maintain control over the provision of their particular services and expertise was hardly smooth. It often required either destroying competitors, as physicians expelled midwives from childbirth, or the development of legitimating procedures by such outside institutions as the university, the teaching hospital, and the state.

Not every aspiring profession obtained the monopolistic control enjoyed by such iconic ones as medicine and the law, but all aspired to the standard model that they exemplified. Some of its main features were:

a.) respect, social status, and a secure and often highly remunerative income

b.) expert knowledge (usually as certified by an educational institution, professional organization, or the state)

c.) workplace autonomy

\section{d.) peer control over access}

e.) a service ethic, often with a code of conduct.

Not every profession adheres to this model. Academics, notably, are employees as well as independent scholars. There are also considerable gradations of status within every profession. Not just money or prestige, but the very work is different-as are the clients. Partners in the big Wall Street law firms advise corporations and negotiate deals but have little in common with the store-front practitioners and jailhouse lawyers who help individuals buy houses, get divorced, and contest D.W.I. violations. True, they all have credentials from law schools, though not necessarily from ones with the same status or access to lucrative careers.

And those credentials - a crucial, perhaps the crucial, element in the professions (provided by the professional academics themselves now under attack) - not only stand in for the expertise that makes up the core of a professional's work, but also serve as a gate-keeping device. They also, along with the profession's traditional ethic of service to its clients and the common good,

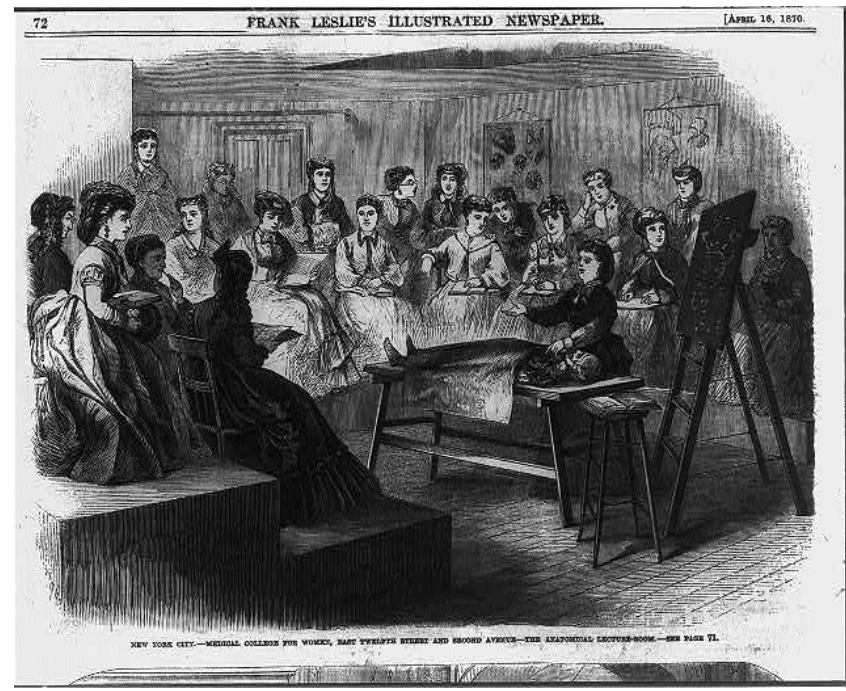

MEDICAL COLLEGE FOR WOMEN. COURTESY OF LIBRARY OF

CONGRESS

legitimize a profession's monopolistic control over its market. Especially when it receives state recognition, such a credential reaffirms the professions' ostensibly meritocratic nature, as an engine of social and economic mobility open to talent and hard work. That claim, as Larson points out, reinforces the American egalitarian myth that conceals modern capitalism's inequitable reality.

Just as there is no platonic form of a profession in North America, much less in all societies, there was no golden age when professions serenely ruled their jurisdictions. Occupational groups struggle against rival practitioners to establish and secure professional autonomy, authority, and privilege. Some make it; some never do; some manage partial and precarious success. And succeeding is not forever, as the articles in this issue of Radical Teacher demonstrate. (See, also in this issue, the review by James Davis of a recent collection on the present condition of the professions). Corporate values and the hierarchical administrative practices that accompany 
them are now undermining most professions, destroying the intrinsic rewards of a professional career, and limiting the ability of professionals to serve the best interests of their clients and the broader community.

Is there a pattern in these ups and downs? Might an historical narrative help find it? We think yes, and would propose a story along these lines: gradually, through the nineteenth century, the traditional professions of law and medicine grounded their practices in bodies of knowledge; elaborated them in journals, conferences, and so on; organized themselves in departments and national organizations; regularized admission to and advancement in their ranks; won the right (often backed by legislation) to exclude rival practitioners; and gained recognition as experts, better pay than most non-professionals, and such perquisites as job security. Other groups strove to professionalize at the same time. University professors (for whom job security was eventually formalized as tenure) are the group best known to readers of Radical Teacher. The lineup also includes engineers, accountants, librarians, nurses, architects, social workers, dentists, and others that consolidated their positions in the early $20^{\text {th }}$ century. A smaller number did so later (e.g., audiologists, on a small scale, around 1950; computer scientists in a disorderly, then triumphal, march through the 1960 s and after). By and large, the professionalizing of new labor groups slowed from 1970 on and older professions began the slide that continues unabated today. What might explain such a story-"explain" in the informal sense of locating it in a broader narrative, and connecting it to the forces and agents that have shaped our world?

\section{We did not need Warren Buffet or, now, Thomas Piketty to teach us that the one-tenth of one percent have won the class war, though it is encouraging to hear the wild ovation greeting Piketty's book, and to hope that Capital in the Twenty- First Century will help secure a permanent place in mainstream media and politics for the central idea of the Occupy movement.}

The first part of such an explanatory move is easy: the professions achieved their modern forms and their prominence just when entrepreneurial capitalism was morphing into a system managed by large, vertically integrated, industrial corporations (Standard Oil, General Electric, U. S. Steel, Procter and Gamble, etc.) that controlled the economic process from the extraction of raw materials through manufacturing all the way to the sales effort. Then, in the 1970s, just as the corporate system began its transition into the casino capitalism we now endure, the professions lost their momentum. In short, the period when professions dominated major fields of mental labor coincided with the peak time of the Fordist regime ("monopoly capital," as Baran and Sweezy called it).
The other part of the explanation is more challenging. For our purposes, a highly schematic sketch will have to suffice. Around 1900, the giant corporations came increasingly to rely on bodies of knowledge built by professionals, especially in science, engineering, business methods, and corporate law. Professionals also took vigorous part in regulating and limiting the rapaciousness of those same corporations, through public organizing and state action; progressive era reform bore the stamp of distinctive professional attitudes and ideology (Wiebe). To that contradiction-professionals both advanced and checked the corporate rise to power-add another. Professions both fought to improve working conditions, health, and safety for the industrial proletariat, and sought to regulate working class life through projects that ranged from rules for nutrition and family hygiene, through public schooling and settlement houses, to legislation against riot, sex, booze, and racial equality. These contradictions were tolerable because through them, corporations got rich, workers' lives improved, and the social order became less cruel and unpredictable. And of course professionals worked them to great advantage. Not only did they win higher pay, prestige, and privilege; their ideology of progress through expertise and rational planning won many adherents, though by no means defeating the bourgeois ideology of competitive individualism. Their leading institutions-the university, the suburb, and so oncame to represent the good life to millions who wanted it for themselves or their children (Ehrenreich and Ehrenreich).

To complete the explanation, we need not only a temporal link (the early 1970s) between the cresting of Fordism and the cresting of the professions, but also causal links. Here, we can do no more than gesture in their direction. We would look for them chiefly in the area of (surprise!) class struggle. At the same time as U.S. capital faced significant economic competition from Europe and Japan, it also found its social order and its imperial war seriously challenged by the $1960 \mathrm{~s}$ movements. It took arms both against those movements and against organized labor, which had gained pay and a small share of workplace control in the postwar period. That campaign relied on casualization, union-busting, stripping away health and retirement benefits, subcontracting, outsourcing, off-shoring, sanctifying free trade, and deskilling work (partly via computer technology). Then, when capital turned hostile attention toward mind-work, it used many of the same weapons against professionals, along with-crucially-the defunding of public services and institutions, including the university. The "fiscal crisis of the state" (O'Connor) provided a framework and method for this attack. Along with the backlash against the campus uprisings of the late sixties, the case against "political correctness" came to rationalize cutting support for the academy. More generally, the work of right-wing foundations, the emergence of Reaganism and then neoliberalism, the spread of libertarianism, the rise of the Tea Party, and so on provided a venomous potion of confused but powerful ideologies to sap the vitality of professions. 
We did not need Warren Buffet or, now, Thomas Piketty to teach us that the one-tenth of one percent have won the class war, though it is encouraging to hear the wild ovation greeting Piketty's book, and to hope that Capital in the Twenty-First Century will help secure a permanent place in mainstream media and politics for the central idea of the Occupy movement. We would just reemphasize here our claim that the victory of the billionaires is making losers of professionals as well as of blue-collar workers. To be sure, not many Ph.D.s and M.D.s are sleeping in homeless shelters, and a minority are doing better than ever. But most new recruits are not, and the professions as institutions are faltering. The articles in this issue of Radical Teacher open windows on their present disorder, though some of our authors would surely contest the hypothesis of a long historical retreat.

That retreat accelerated in the crash of 2008: could an economic recovery win back lost ground? We are skeptical. Six years later, state funding has returned (spottily) to our sector of the academic profession (the humanities), and the gap between the number of new doctorates and the number of tenure track job listings has narrowed a bit. We do not expect it to return to prerecession levels, miserable though they were. We will not try to "prove" this conjecture, just make three observations that give it initial plausibility.

First, after the academic job market tanked, in the early 1970s (when the U.S. working class also stopped making economic gains), and after at least two subsequent recessions, tenure-track employment in the humanities did not bounce back to its previous levels, relative to the growth of higher education. Structural change occurred; adjuncts were hired to do more of the teaching that tenure-track faculty members used to do. That restructuring was reflected in the size of scholarly and professional organizations: for instance, membership in the Modern Language Association dropped from over 30,000 members in 1970 to about 28,000 now, while postsecondary enrollment in the United States was doubling. Membership in the American Association of University Professors dropped by half, in the same periodi.e. by $75 \%$ relative to the number of college and university students. Second, the post-2008 economic recovery has in general benefited the rich a good deal, the $99 \%$ relatively little. It would be strange if such an upward redistribution of income and wealth returned higher education to its former prosperity. Third, unless there are radical changes, processes such as the privatizing of public services, the ballooning of college administrations, and the digitalizing of almost everything, which have gnawed away at academic labor for decades, seem unlikely to go into reverse.

Comparisons with other professions would be instructive, but impossible to do in the time and space available for this introduction. So we simply reiterate our belief that if the reconfiguring of our political economy that has gone on apace for 40 years continues along the same lines, there is no reason to expect it to become more hospitable to professions than it has been so far. Crises in energy, food, and the ecological underpinnings of our civilization seem likely to make things still worse. Of course if the earth fries, survivors will have more to worry about than the well-being of professors and lawyers. Short of apocalypse, though, people in the professions will worry, and will need to think strategically.

It may be handy to think of radicals in the professions as presented with a strategic choice: work to rebuild the structures, the power, and the market havens we had in the 1960 s or cast our lot with the traditional working class and the ever broadening swath of it now often called the "precariat." Of course, the two projects are not mutually exclusive. Regaining at least some of the professions' traditional autonomy, economic security, and ability to transcend the marketplace almost certainly requires coalitions with workers in other sectors - i.e. the $99 \%$. Whether those coalitions develop within traditional labor unions or some new political formation, once professionals opt for solidarity with - instead of superiority over - their clients and fellow workers (a non-trivial project), they might be able to restore some of their lost autonomy. They might even regain the power to direct their research from the corporations that have been assiduously privatizing it, as well as contribute to the movement for a more just society. Science for the people is as sound an idea now as it was in 1970. Just to take one obvious example, both medical professionals and their patients would benefit from a single-payer healthcare system and the socializing of medical research.

\section{Meanwhile, until either socialist revolution or the collapse of civilization occurs, there will doubtless be ordinary teaching days, department meetings, curriculum planning sessions, and proposals before the faculty senate. The essays in this issue of Radical Teacher point toward practical issues for left practitioners in $K-12$, undergraduate, graduate, or professional education to engage.}

No one route will take us to where we want to go. In the short term, as McNally and Oliphant imply, unionization (or its equivalent in right-to-work states and other places where the NLRB does not reach) may well provide the most effective tactic. For academics, that means overcoming the status divisions within our profession and supporting, even joining, the organizing efforts of TA's and part-timers, not to mention the secretaries, janitors, and other campus workers, all of whom confront the same corporatizing administrators. We could seek broader alliances, as well, with other declining professionals and with our students whose disastrous indebtedness stems from the same defunding of the public sector that now guts the professoriate. Ultimately, we need a broad-based social movement that contests the power of the plutocrats on every front. 
Meanwhile, until either socialist revolution or the collapse of civilization occurs, there will doubtless be ordinary teaching days, department meetings, curriculum planning sessions, and proposals before the faculty senate. The essays in this issue of Radical Teacher point toward practical issues for left practitioners in $\mathrm{K}-12$, undergraduate, graduate, or professional education to engage. How, for example, should we modify our own pedagogy and scholarship?

As they grapple with those issues, our authors range from the classroom to the courtroom, raising questions and suggesting possible ways to resist the deskilling and precarity that today's capitalist system imposes on professionals. Though they produce no easy answers, their proposals and analyses, by revealing the ubiquity and similarity of the problems the professions face, may perhaps encourage us to think in broader terms and to take at least some steps toward the collective action that we so desperately need.

Jeffrey Williams, for example, explains how he transforms the decline of the professions into a literal teaching moment by offering a course on the subject. One can imagine the value of such an exercise in mobilizing student support for the TAs and adjunct instructors who might presumably teach such a course. As she updates her earlier historical analysis of the professions, Magali Sarfatti Larson also explores the current situation of $\mathrm{K}-12$ teachers and their unions. Several other authors - Chris Anderson, Paul Campos, and Michael Olivas - address the dilemma of the professional schools that produce graduates for the increasingly elusive careers in law and journalism. That they can find little consensus attests to the intractability of the problem - especially if handled within the parameters of current capitalism's common sense.

We did not ask our authors specifically to discuss how computers contributed to the decline of their professions; but several, including Matt Anderson, Tami Oliphant, and Michael McNally, write of ways in which technology, along with the commercialization and mechanization of information, allows privatizers, corporations, and state regulators to undermine the expertise and ability of highly trained professionals to serve their traditional clients. Claire Bond Potter, on the other hand, offers an upbeat assessment of the prospects for digitizing academic work that could, she claims, offer new opportunities to endangered professors and their students. We are more resistant to Potter's optimism than we would like to be. We have seen too many techno-bubbles and failed academic utopias to rest a lot of hope in technological or entrepreneurial fixes.

Still, these essays do not leave us in a slough of despond. We can, for example, take encouragement from such organizing gains as those of the $\mathrm{K}-12$ union in
Chicago, the agreement just reached (after five years without a contract) between their counterparts in New York City and the de Blasio administration, and the achievement, this spring, of collective bargaining rights by faculty unionists at the University of Illinois at Chicago. Similarly, Piketty's ascent onto the best-seller list may signal a long-overdue change in the ideological climate. Certainly, we are not about to abandon the struggle for a decent society. Who knows, we might even win - some day.

\section{Sources}

Abbott, Andrew, The System of Professions: An Essay on the Division of Expert Labor (Chicago: University of Chicago Press, 1988).

Baran, Paul A. and Paul M. Sweezy, Monopoly Capital: An Essay on the American Economic and Social Order (New York: Monthly Review Press, 1968).

Ehrenreich, Barbara and John "The Professional-Managerial Class," Radical America, Part 1, 11 (March-April 1977): 7-31; Part 2, 11 (May-June 1977): 7-22.

Larson, Magali Sarfatti, The Rise of Professionalism: A Sociological Analysis (Berkeley and Los Angeles: University of California Press, 1977).

O'Connor, James, The Fiscal Crisis of the State (New York: St. Martin's Press, 1973).

Stewart, James, B., "A Lawyer and Partner and Also Bankrupt," NY Times, Jan. 25, 2014

Wiebe, Robert, The Search for Order (New York: Hill and Wang, 1966). $(\mathrm{cc})$ EY-NG-ND This work is licensed under a Creative Commons Attribution-Noncommercial-No Derivative Works 3.0 United States License.

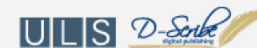

This journal is published by the University Library System of the University of Pittsburgh as part of its D-Scribe Digital Publishing Program, and is cosponsored by the University of Pittsburgh Press.
RADICAL TEACHER 